\title{
THE IMPACT OF EXTERNAL DEBT ON ECONOMIC GROWTH IN GHANA: A COINTEGRATION ANALYSIS
}

\author{
J. M. Frimpong' and E. F. Oteng-Abayie ${ }^{2}$ \\ 'KNUST School of Business, Kwame Nkrumah University \\ of Science \& Technology, Ghana \\ 'School of Business Studies, \\ Garden City University College. \\ Kumasi, Ghana
}

\begin{abstract}
A plethora of both cross-country and country-specific studies have been undertaken to estimate the impact of external debt on growth in developing countries. Their general findings though revealing need to be confirmed in Ghana. This paper estimates empirically the impact of external debt on economic growth in Ghana to determine the existence of a 'debt overhang' and/or 'crowding out' effects for the period 1970 to 1999. We used the ADF, PP and KPSS tests for unit roots and the Johansen-Juselius maltivariate approach to cointegration to test for stationarity and a long-run relationship among variables. A vector error correction model (VECM) was used to estimate the short-run impacts. The results indicate that GDP growth is influenced positively by external debr inflows and negatively by deht servicing revealing the presence of a 'crowding out effect'. An indication of a 'debt overhang effect' is also found through the negative impact of domestic investment.
\end{abstract}

Keywords: external deht, deht servicing, economic growth, whit roots, cointegration, Ghana

\section{INTRODUCTION}

Various studies have analyzed the impact of external debt on economic growth. Broadly, these studies can be classified into two groups: (i) cross-country studies using groups of developing countries: Elbadawi et al (1996), Fosu (1996), UNECA (1998). Iyoha (1999), Serieux and Yiagadeesen (2001) and (ii) country specific studies: Degefe (1992) for Ethiopia. Mbanga (2001) for Cameroon, Were (2001) for Kenya, and Mwaba (2001) for Uganda. The country case studies purely applied time series data analysis for specific countries to mostly confirm broad conclusions from cross-country studies.

These studies attempt to estimate the impact of key debt variables as determinants of GDP growth. Majority of the existing studies report a negative impact of external debt accumulation and debt servicing on growth, notwithstanding differences in methodological approaches. However, some find positive impacts for current external debt inflows. Though their findings and conclusions are quite revealing, there is still the

122 journal of science and technology, volume 26 no. 3, December, 2006 
need for case-by-case studies in view of each country's unique characteristics, to contribute to applied research and policy-making.

This paper analyzes, for the first time, the impact of external debt on GDP growth in Ghana using a multivariate cointegration approach. Ghana represents a good case study for different reasons. First, Ghana is among the group of Highly Indebted Poor Countries (HIPC) countries that have been granted total debt cancellation by the G8 countries in July 2005. Second, Ghana has had a history of debt servicing problems during which it had difficulties in honouring its external debt servicing obligations. The external debt problems of Ghana which are similar to other HIPC Sub-Saharan African (SSA) countries have been compounded by massive poverty, economic structural weaknesses, moral hazards, and weak institutional capacities. Whatever the reasons that may have led to the unprecedented surge in the debt burdens, Ghana repeatedly resort to borrowing from the non-concessionary window of the IMF such as the Standby Facility simply to service accumulated debts (BoG, 2005). This trend limits sustainable economic growth.

The main objective of this paper is to estimate the impact of external debt on growth and to determine whether there exist 'debt overhang' and/or 'crowding out' effects in Ghana based on data covering the period 1970-1999. We follow the recent study by (Elbadawi et al, 1996) to build a model for Ghana.

The paper proceeds with a snapshot of the evolution of debt in Ghana, an overview of the debtgrowth literature, methodology and data issues, reporting and discussion of the empirical results and then concludes.

\section{Evolution of Ghana's External Debt}

Ghana's external debt increased considerably after the implementation of the economic recovery and structural adjustment programmes. During the early 1980 s, Ghana faced a debt problem with external debt payments hitting as $h i \mathrm{~h}$ as US $\$ 577$ million (114\% of GDP) at the e $d$ of 1982. This debt crisis was as a result of oil price hikes on the international market, sharp rises in international interest rates, recession in the West, against the backdrop of poor economic policies and management of the domestic econ my. Ghana's public and publicly guaranteed debt reached US\$6 billion in nominal terms at the end of 2000 , including arrears of US $\$ 81$ million. Ghana's external debt in net present value terms reached US\$3.9billion, representing about 571 per cent of fiscal revenue, 157 percent of exports of goods and non-factor services and 78 percent of GDP. At the end of 2000 , multilateral creditors accounted for 65.6 percent of the overall nominal value of external debt before full use of traditional debt-relief mechanisms. Bilateral creditors represented 27.9 percent of the total external debt in nominal terms, Paris Club creditors represented 26.5 percent of the total debt outstanding, other official bilateral creditors accounted for 1.4 percent and commercial creditors represented 6.4 percent of the outstanding debt in the ensuing year.

The nature of Ghana's external debt is very crucial in terms of future debt repayments. In 2000 , out of the US\$6,062 million external debt, the long-term component of the external debt stock represented 87.8 percent, 4.7 percent short-term debt and 7.5 percent accounts for medium-term debt. This has implications for Ghana's debt sustainability. Ghana adopted the HIPC debt relief to provide adequate financial resources to service its external debts on a sustainable basis and spend the freed resources on priority areas as identified in the Ghana Poverty Reduction Strategy (GPRS) document. The high ratio of the total external debt in relation to GDP indicated that Ghana stood the risk of having accumulated debt, which may be unsustainable in the long run. This trend if not checked may have led the country into another debt crisis, which may render the country a credit unworthiness status. See Bank of Ghana Research Paper on HIPC (BoG, 
2005) for a critical assessment of the evolution of external debt and debt servicing problems in Ghana.

\section{Recent Literature}

A plethora of studies have been undertaken to estimate the impact of external debt on growth. Their main theme has been whether there is 'debt overhang' and/or 'crowding out' effects. The econometric models used to estimate the impact of external debt on growth are dictated by the augmented neoclassical growth model postulated by economic theory. From the theory, there is an incentive for capital-constraint countries to borrow and invest since the marginal product of capital is above the world interest rate. Thus, reasonable levels of external debt are expected to have a positive impact on growth.

The debt-growth nexus have been explained through two main channels: (i) the stock of accumulated debt (debt overhang effect) and (ii) debt servicing (crowding-out effect). The 'debt overhang effect' argues that if there is some likelihood that in the future debt will be larger than the country's repayment ability, then expected debt service will be an increasing function of the country's output (growth) level. The returns from investment in the domestic economy therefore face a high marginal tax by the external creditors, and new domestic and foreign investment is discouraged (Krugman, 1988; Sachs, 1989). Claessens and Diwan (1989), defined debt overhang as a condition where outstanding debt is so large that investment will be inefficiently low without sizeable debt or debt service reduction. This implies that debt reduction will lead to increased investment and debt service capacity and the prospect that, the amount of the debt outstanding would be repaid.

The 'crowding out effect' is the other channel with implication for a negative impact of external debt on investment and growth. Cohen (1993) rejects the debt overhang effect arguing, that the important debt problem is the crowding out of investment caused by debt servicing. In the crowding out effect, a reduction in the current debt service payments should lead to an increase in current investment or any given level of future indebtedness. A high debt burden generally means that a significant portion of government fiscal revenue (budget resources) or export receipts must be devoted to debt servicing. If options for short-term increases in revenue are exhausted, other areas of government spending and productive public investments will be cut to accommodate debt servicing. Reduced public investment, if complementary to private investments, can ultimately lead to lower growth rates (Diaz-Alejandro, 1981). Experience has showed that over-borrowing becomes a negative spiral and, if the costs of debt servicing are not internalized, new loans serve as debt repayment without any positive impact on growth.

Elbadawi, et al (1996) use a non-linear fixed effects panel estimation to establish the linkages between external debt and investment and growth. Using cross-section data for 99 developing countries, including Sub-Saharan African (SSA) countries they estimated a growth and investment equation model. Their conclusions supported theory that, current debt inflows spur GDP growth while past (lagged) accumulated debt works against growth. This implies that beyond a certain level, debt accumulation will discourage investment and retard growth. The results showed that there is evidence of both debt overhang and crowding out effects from excessive external debt burdens on growth and investment in developing countries. Studies by UNECA (1998) and lyoha (1999) supported the conclusions of Elbadawi et al (1996).

Most work in the growth literature rely simply on cross-country regressions. The weakness of this approach is that what appears to hold on average is rarely an adequate explanation of what is happening in a particular country (Zupi, 2003). Mwaba and Were $(200.1,2001)$ have also estimated the external debt impacts on growth for Uganda and Kenya based on Elbadawi's debt-growth-investment model formulation with 
specific country modifications to test the results from Elbadawi et al (1996). Mwaba (2001) used a basic growth equation model in a simple Ordinary Least Squares (OLS) regression to test the hypothesis that accumulated debt negatively affects growth in Uganda. The estimations returned the expected hypothesis for the debt variable in Uganda. While accumulated debt returned a negative and significant effect on GDP growth, current debt inflows had a positive impact in Uganda. Were (2001) also estimated the impact of Kenya's external debt on economic growth and private investments. She also specified a growth and investment equation model based on Elbadawi (1996) specifications. Using time-series data for the period"1970-1995, her results also indicated that debt accumulation has a negative impact on economic growth. This finding confirms the existence of a debt overhang problem in Kenya.

\section{METHODOLOGY AND DATA COLLECTION}

In general, existing studies report a negative effect of accumulated external debt on growth in developing countries, in spite of differences in methodological approaches. Although there are many different specifications of the growth relations, most of the studies include a fairly standard set of debt, policy and other exogenous explanatory variables depending on the focus of the study.

Following a modified specification of the growth equation estimated by Elbadawi's (1996) for developing countries and used by both Were (2001) for Kenya and Mwaba (2001) for Uganda, a growth equation for Ghana is estimated employing as explanatory variables debt and economic variables. The following linear semi-log specification for the long run growth and external debt impact is employed:

$$
\begin{aligned}
& Y_{1}=\alpha_{0}+\alpha_{l} \ln E D T_{1}+\alpha_{2} \ln T D S_{1}+\alpha_{3} \ln I N V_{1}+\alpha_{4} \\
& \ln F D I_{1}+\alpha_{5} E X P_{1}+\varepsilon_{1}
\end{aligned}
$$

where the dependent variable $Y_{t}$ is GDP growth. $I N V_{1}$ is gross domestic investment to GDP ratio which is expected to have a significant positive influence on GDP growth. EDT, is the ratio of total external debt to GDP; TDS $_{\mathrm{t}}$ is total debt service to exports ratio (to capture crowding out effects). Consistent with the growth models, (a priori) we expect the coefficient on current external debt inflows to be positive. Debt service ratio is expected to be negative due to the reductions in domestic investment expenditures from debt service payments. EXP, is the annual growth rate of export capacity to import (proxy for an open economy). $\mathrm{FDI}_{t}$ is foreign direct investment as a ratio of GDP measuring complementary external resource inflow, and we expect a limited positive impact on growth. There are a number of potential determinants of GDP growth that have not been included in our specification, such as aid flows, fiscal balance, and population growth. Their exclusion is unavoidable due to the degrees of freedom available, on account of the short time series availability. Also, the decision to exclude demographic variables was taken because these are generally treated as weakly exogenous, and so are of limited interest to our study. In this study, annual time-series data for the period 1970 to 1999 are used. Data for all the series are obtained mainly from the World Bank's World Development Indicators CD-Rom.

In order to model the variables in a manner that captures the inherent characteristics of its timeseries, we use the Akaike Information Criterion (AIC), Schwartz Information Criterion (SIC), and Log-Likelihood ratio to determine the lag structure of the series. We test for the existence of a long-run relationship among the variables (estimation of equation (1)) whiles the utilization of the vector error correction model captures the short-run dynamics of the variables. The analysis is done in three steps. The first step is to verify the order of integration of the variables since the various cointegration tests are valid only if the variables have the same order of integration. Standard tests for the presence of unit root based 
on the Augmented Dickey-Fuller (ADF) (1979, 1981), and Phillips-Perron (1988) are used to investigate the degree of integration of the variables used in the empirical analysis. Given that the ADF tests is sensitive to small samples, we also used the KPSS test (Kwiatkowski et al., 1992) to confirm the robustness of the Augmented Dickey-Fuller (ADF) and PP test results. The second step involves testing for cointegration relationships using the Johansen cointegration test (Johansen, 1988). The Johansen estimation method is based on the error-correction representation of the VAR model with Gaussian errors. Evidence of cointegration rules out the possibility that the estimated relationship is spurious. Thus, the third step involves utilization of the VECM. We invoke the Engle-Granger theorem (1987) which states that in the presence of cointegration, there always exists a corresponding error-correction representation which implies that changes in the dependent variable are a function of the level of disequilibrium in the cointegrating relationship, captured by the errorcorrection term (ECT), as well as changes in other explanatory variables to capture all short run relations among variables.

\section{RESULTS}

Table 1 presents the ADF, PP and KPSS tests for the variables in levels and first difference. The usefulness of the PP test over the ADF is that it allows for the possibility of heteroscedastic error terms. The lag length in the PP test was selected based on the Newey-West criteria (Newey and West, 1994). To check for the robustness of the ADF and PP test results, the KPSS test is also reported. Here the null hypothesis of stationarity is tested.

The results, shown in the last two columns in Table 1, indicate that the null hypothesis of level stationarity can be rejected for all variables. The combined results from all the tests suggest that all the variables are $I(1)$ in levels but $I(0)$ in first difference with the exception of $Y_{t}$ and variable which is $I(0)$ at the level. The results of the unit root underscore the presence of nonstationarity in the variables and the adverse consequences of neglecting it.

According to Engle and Granger (1987), if two or more variables are cointegrated (i.e. they exhibit long-run equilibrium relationships and therefore share common trends) then the cointe-

Table 1: ADF, PP and KPSS Tests for Stationarity in Variables

$\mathrm{H}_{0}$ : unit roots $\mathrm{I}(\mathrm{l}) . \mathrm{H}_{1}$ : trend stationary I $(0) . \quad \mathrm{H}_{0}: \mathrm{I}(0)$

\begin{tabular}{|c|c|c|c|c|c|c|}
\hline \multirow[b]{2}{*}{ Variable } & \multicolumn{2}{|c|}{ ADF } & \multicolumn{2}{|c|}{ PP } & \multicolumn{2}{|c|}{ KPSS } \\
\hline & Level & Diff. & Level & Diff. & Level & Diff. \\
\hline$Y_{\text {I }}$ & $-4.511 * * *$ & $-5.490 * * *$ & $-4.834^{* * *}$ & $-6.928^{* * *}$ & $0.0897 * *$ & $0.0499 * *$ \\
\hline$E D T$, & -2.488 & $-3.489 * * *$ & -2.745 & $-5.623^{* * *}$ & 0.1161 & $0.0845^{* *}$ \\
\hline$D S R_{i}$ & -1.691 & $-3.898 * *$ & -1.393 & $-3.810 * *$ & 0.2427 & $0.0596 * *$ \\
\hline$E X P_{t}$ & -2.618 & $-4.269 * *$ & $-4.068 * *$ & $-9.539 * * *$ & 0.3108 & $0.0929 * *$ \\
\hline$I N V_{t}$ & -2.209 & $-5.207 * * *$ & -2.614 & $-6.939 * * *$ & 0.2473 & $0.0995 * *$ \\
\hline FDI, & -2.679 & -3.178 & -3.126 & $-4.341 * *$ & 0.1923 & $0.1253 * *$ \\
\hline$G D P P C$ & -2.447 & $-4.670 * * *$ & -2.344 & $-4.889 * * *$ & 0.3621 & $0.0524 * *$ \\
\hline
\end{tabular}

Notes: Significant coefficients are indicated by *,**,***, for significance at the $10 \%, 5 \%$ and $1 \%$ level, respectively. The MacKinnon critical values for ADF and PP tests are $-3.237(10 \%),-3.603(5 \%)$, and -4.374 $(1 \%$. The KPSS $10 \%$ and $5 \%$ critical values for stationarity around a level and around a deterministic linear trend are 0.119 and 0.146 , respectively. 
Table 2: Johansen's Test For Number of Cointegration Vectors Among Variables

\begin{tabular}{cccccc}
\hline$H 0:$ & $H I:$ & Eigenvalue & $\begin{array}{c}\text { LR test } \\
\text { statistic }\end{array}$ & $\begin{array}{c}\text { 5 Percent Critical } \\
\text { Value }\end{array}$ & $\begin{array}{c}\text { I Percent Critical } \\
\text { Value }\end{array}$ \\
\hline$r=0$ & $r=I^{* *}$ & 0.999537 & $241.1203^{* *}$ & 94.1500 & 103.18 \\
$r \leq 1$ & $r \geq 2$ & 0.698992 & 64.53035 & 68.5200 & 76.07 \\
$r \leq 2$ & $r \geq 3$ & 0.525639 & 36.91609 & 47.2100 & 54.46 \\
$r \leq 3$ & $r \geq 4$ & 0.462068 & 19.76299 & 29.6800 & 35.65 \\
$r \leq 4$ & $r \geq 5$ & 0.198354 & 5.502482 & 15.4100 & 20.04 \\
\hline
\end{tabular}

Note: ${ }^{*}\left({ }^{* *}\right)$ denotes rejection of the mill hypothesis at $5 \%(1 \%)$ significance level.

gration among variables rules out the possibility of the estimated relationships being "spurious". We now use the Johansen cointegration procedure to tests for the number of cointegrating vectors. The Johansen procedure, unlike the Engle-Granger procedure is not sensitive to the choice of dependent variable and aiso assumes all variables to be endogenous (Masih and $\mathrm{Ma}-$ sih, 2000). We use a general-to-specific modeling approach (Hendry and Krolzig. 2001) to first specify the relevant order of lags $(p)$ of the restricted Vector Autoregression model (VAR(p)). Given the annual nature of the data, $p=1$ seems to be a reasonable choice based on the AIC, SIC and LR information. Table 2 presents the results obtained from the cointegration test.

In Table 2 column 4 , the results of the loglikelihood (LR) test statistics are reported. Start- ing with the null hypothesis of no c: itegration $(r=0)$ among the six variables of $\gamma, I D T$, TDS, INV, FDI, and EXP, the trace statistic suggest 1 cointegrating vector $(\mathrm{r}=1)$ at $1 \%$ significance level. Therefore, we conclude that there is only one cointegrating relation among the variables.

These findings establish the existence of an underlying long-run equilibrium relationship between the dependent variable GDP growth and all the explanatory variables: external debt (EDT), debt servicing (TDS), gross domestic investment (INV), foreign direct investment (FDI), and export as a capacity to import (EXP). The normalized long-run growth equation is presented in Table 3.

The model shows theoretically correct signs for the explanatory variables with the exception of the gross domestic investment variable which is

Table 3: The Normalized Long run Growth Equation for the Cointegration Test

\begin{tabular}{|c|c|c|c|}
\hline \multicolumn{4}{|c|}{ Dependent variable: $Y_{t}$} \\
\hline Explanatory variables & Coefficient & t-statistics & p-value \\
\hline Constant & -0.132485 & & \\
\hline $\ln I N F_{1}$ & -0.061754 & $-3.84892^{*}$ & 0.00073 \\
\hline$E Y P_{1}$ & 0.034779 & 1.29671 & 0.20657 \\
\hline In $F D I$ & 0.011382 & $2.10362 * *$ & 0.04564 \\
\hline In TDS & -0.051906 & $-2.96634^{*}$ & 0.00655 \\
\hline LnEDT, & 0.061638 & $2.53599 * *$ & 0.01784 \\
\hline
\end{tabular}


incorrectly signed. All the variables are significant, except the export as a capacity to import variable which is insignificant. The signs on the debt variables support the theoretical conclusion. The significant positive sign on the current debt variable $(E D T=0.0616)$ implies that current external debt stock promotes GDP growth by increasing capital imports and other tradable goods that drive the economy during the period of accumulating external debt. Since the "crowding out effect" variable (TDS $=-0.0519$ ) is highly significant, there is clear evidence of a "crowding out" effect of debt servicing. The negative sign, as postulated by theory, is to depress the level of investment. This implies that substantial portions of government fiscal revenues, export receipts and new borrowings are used to service the high debt service requirements instead of investing in productive projects. Thus the overall benefit from borrowing is offset by the high cost of debt servicing. This was exactly the picture for Ghana before it adopted the enhanced HIPC initiative in 2001. Ghana had to borrow more, even from the nonconcessionary window of the IMF such as the Standby Facility, just to service its debt (BoG, 2005). The low elasticities of the external debt impacts however are underlined by the concessional nature of Ghana's debt profile. .

Gross domestic investment (INV $=-0.0617)$ was negative and statistically significant in all regres. sions. This is an indication of the "debt overhang effect" as postulated by Krugman, (1988); Sachs (1989) and; Claessens and Diwan (1989). As already explained in the literature section, the debt overhang acts like a high marginal tax rate on the country lowering the returns to investment and providing a disincentive to domestic capital formation. The debt overhang indirectly depresses the level of GDP by discouraging capital formation and encouraging capital flight due to tax increase expectations. Thus domestic investment becomes inefficiently low to make significant positive impacts on GDP growth. The overall long-run result is consistent with the studies of Iyoha (1997) for sub-Saharan African countries; Elbadawi et al (1997) for developing countries; and Mwaba (2001) for Uganda.

Having established that a cointegrating relationship exists among the variables, a Vector ErrorCorrection Model (VECM) is estimated to determine the dynamic behaviour of the growth equation in the short-run. We estimate the short run VECM (equation 2) based on the following specifications derived from a general-to-specific modelling:

$$
\begin{aligned}
& \left.\Delta Y_{1}=\beta_{0} \sum_{i=1}^{n} \beta_{1 i} \Delta Y_{i-i}+\sum_{i=1}^{n} \beta_{2 i} \Delta \mid n E I\right) T_{i-1}+ \\
& \sum_{i=0}^{n} \beta_{3 i} \Delta \ln 77 S_{i-i}+\sum_{i=0}^{n} \beta_{4 i} \Delta \ln I N T_{1-i}+ \\
& \sum_{i=0}^{n} \beta_{5 i} \Delta \ln F P_{t-i}+\sum_{i=0}^{n} \beta_{6 i} \Delta E X P_{t-i}+\beta_{7} E C T_{t,-1} \\
& +\beta_{8} \operatorname{In} G D P P C+\mu_{1}
\end{aligned}
$$

where all the variables are as previously defined except $\Delta$ which represents change and $E C T_{1-1}$ which is the one period lagged error correction term estimated from equation (2). The coefficient measures the speed of adjustment to obtain equilibrium in the event of shocks to the system. $\ln G D P P C$ is the natural logarithm of the initial level of per capita GDP. This is used as an exogenous variable in the VECM to capture the conditional convergence effect and is expected to have a significant negative influence on the growth.

In the short run dynamic growth equation, presented in Table 4, the coefficients of the debt variables provide interesting results as they maintain their signs as in the long run equation. The lagged debt service variable is not statistically significant though with the expected negative impact. The lagged debt ratio, which also captures debt overhang effect, however did not come out with the expected negative impact. This 
Table 4: Short Run Error Correction Growth Equation

Dependent Variable: $\Delta Y_{t}$

\begin{tabular}{|c|c|c|c|c|}
\hline Variable & Coefficient & Std. Error & t-Statistic & Prob. \\
\hline Constant & 0.001156 & 0.00059 & 1.960919 & 0.0701 \\
\hline$A Y_{t-1}$ & -1.00285 & 0.016156 & -62.0736 & $0.000 *$ \\
\hline $\ln \mid N V_{1-1}$ & -0.01365 & 0.002453 & -5.56567 & $0.0001^{*}$ \\
\hline$\triangle E X P_{1-1}$ & 0.015551 & 0.003916 & 3.971338 & $0.0014^{*}$ \\
\hline$A \ln F D I_{t-1}$ & 0.0000427 & 0.000756 & 0.564638 & 0.5813 \\
\hline $\operatorname{Lin} T D S_{t-1}$ & -0.00214 & 0.001952 & -1.09596 & 0.2916 \\
\hline$A \ln E D T_{1-1}$ & 0.018147 & 0.005471 & 3.317017 & $0.0051 *$ \\
\hline $\operatorname{An}(G D P P C$ & 1.020292 & 0.018803 & 54.26173 & $0.000^{*}$ \\
\hline$E C T_{t-1}$ & -1.01992 & 0.015302 & $-66,6523$ & $0.000^{*}$ \\
\hline$R^{-}$ & 0.998 & & $X_{\text {Hald }}^{2}$ & $865.243^{*}$ \\
\hline$A d j . R^{2}$ & 0.997 & & $\chi_{\text {Norm }}^{2}$ & 0.703 \\
\hline F-statistic & $967.304 *$ & & $\chi_{\text {Reset }}^{2}$ & .560 \\
\hline I og likelihood & 112.124 & & $x_{\text {two }}^{2}$ & 0.0139 \\
\hline Akaike info criterion & -8.967 & & $\chi_{A R C H}^{2}$ & 1.618 \\
\hline Schwar/ critcrion & -8.523 & & $x_{\text {white }}^{2}$ & 2.183 \\
\hline
\end{tabular}

Note: * denotes statistical significance at the $1 \%$ level

implies that in the short run external debt accumulation may have positive impact on growth. The negative effect of the investment variable, however, is an indication of the presence of a 'debt overhang effect' in the short run. The low elasticity of the lagged debt ratio further suggests that growth is not very sensitive to short run changes in the accumulated debt stock. One underlying reason can be attributed to the relatively large concessional and long-term nature of Ghana's external debt compared to other developing countries such as Argentina, Mexico, and Nigeria.

The estimated coefficient of the error correction term is statistically significant at the 1 percent level and with the appropriate (negative) sign, reflecting the joint significance of the long-run coefficients. This suggests the validity of a longrun equilibrium relationship among the variables in equation (1). The estimated coefficient value of more than a unit $(-1.01)$ suggests that the systen corrects its previous period's disequilibrium completely within one year to its equilibrium level following a shock. The ECT $T_{\mathrm{t}-1}$ coefficient however, indicates possible overshooting. Diagnostic test statistics show no evidence of misspecification of functional form (Reset), no serial correlation, or any problem of heteroscedasticity. The model also passes the normality, Wald, ARCH and stability tests (Table 4).

\section{SUMMARY AND CONCLUSIONS}

The purpose of this paper was to estimate the impact of external debt on growth in Ghana using time series analysis. The keystone of our 
analysis is an Elbadawi-growth-equation model in which growth depends on gross domestic investment, foreign direct investment, debt servicing, external debt inflows and export capacity.

The empirical results support the existence of a long-run growth equation in Ghana. Over the long-run period, external debt inflows, debt servicing and foreign direct investments affect GDP growth behaviour. An increase in external debt inflows has a positive effect on GDP growth. An increase in external debt servicing decreases GDP growth and there is evidence for the existence of the 'crowding out effect' in Ghana. Foreign direct investment has a positive and significant influence on GDP growth behaviour. Investment has an unexpected negative and significant impact on growth. This result is an indication of the long-run "debt overhang effect" of high accumulated debt which acts as a disincentive to capital formation and encourages capital flight. Thus the low levels of domestic investments in the real sectors of the economy are not able to make positive impact on growth.

The empirical results from the short run vector error-correction model (VECM) estimation support the presence of a 'debt overhang effect' of high accumulated debt through the investment variable which has a negative and significant impact on growth. The crowding out effect is also confirmed. The GDP growth decreases as total debt service increases.

The results have important policy implications for Ghana. It justifies the adoption of the HIPC debt relief initiative because in the long run Ghana is bound to have debt servicing problems that can be offset by substantial debt relief or total debt cancellation. Moreover, the presence of a 'crowding out effect' and a 'debt overhang effect' in the long run means that the efficiency of total investments will suffer as government cuts its budgets, tax returns on private investments, or uses capital inflows to service its external debt obligations. Preliminary evidence from Ghana's current debt relief under HIPC
(BoG, 2005) suggests a substantial reduction in debt servicing requirements and an increase in social investment expenditure. This has significant implication for poverty reduction and economic growth.

Another implication of our analysis is that policies that spur domestic investments, foreign direct investment and increased trade earnings can be effective in raising GDP growth and reducing dependence on external debt for sustained economic development.

\section{REFERENCES}

Barro, R. J. and Sala-1-Martin, X.X. (1992). Convergence: Journal of Political Economy, 100: 223-251.

BoG (2005). The HIPC Initiative and Ghana's External Debt: An empírical assessment and Policy challenges. Policy Brief, Special Studies, Research Department, Bank of Ghana.

Borensztein, E. (1990). Debt overhang, debt reduction and investment: The case of the Philippines. IMF Working Paper No. WP/90/77, September.

Cohen, D., (1993). Low investment and Large LDC debt in the 1980s. The American Economic Review, June 1993.

Degefe, B. (1992). Growth and foreign debt: The Ethiopian experience: 1964-86. AERC Research Paper 13, Nairobi.

Dickey, D.A., and Fuller W.A. (1979). Distribution of the Estimator for Autoregressive Time Series with a Unit Root. Journal of the American Statistical Association, 74:427-31.

Diwan, I. and Claessens, S. (1989). Liquidity, Debt Relief and Conditionality. In: Diwan, I. (Editor), Dealing with the Debt crisis, $A$ World Bank Symposium Volume, Washington, DC: World Bank.

Elbadawi I., Benno N., and Njuguna, N. (1996). Debt Overhang and Economic Growth in Sub-Saharan Africa. In: Iqbal, Zubair and Ravi (Editors) External Finance for Low- 
Income Countries. Washington DC: IMF Institute

Engle, R.F. and Granger, C.W.J (1987). Cointegration and Error Correction: Representation, Estimation and Testing. Econometrica, 55: 251-76.

Fosu, A.K. (1996). The Impact of External Debt on Economic Growth in Sub-Saharan Africa. Journal of Economic Development, 21, 1: 93-117.

Hendry, D.F. and Krolzig, H.M. (2001). Automatic Econometric Model Selection Using PCGets, London: Timberlake Consultants Press.

Iyoha, M.A. (1999). External Debt and Economic growth in Sub-Saharan African Countries: An econometric study. AERC Research Paper 90, African Economic Research Consortium, Nairobi.

Johansen, S. (1.988). Statistical Analysis of Cointegrating Vectors. Journal of Economic Dynamic and Control, 12:231-54.

Johansen, S. and Juselius, K. (1990). Maximum Likelihood Estimation and Inference on Cointegration with Applications the Demand for Money. Oxford Bulletin of Economics and Statistics, 52, 2: 169-210.

Krugman, P. (1988). Financing Vs Forgiving a Debt Overhang. Journal of Development Economics, 29: 252-268.

Kwiatkowski, D., Phillips, P., Schmidt, P., and Shin, Y. (1992). Testing the Null of Stationarity Against the Alternative of a Unit Root. Journal of Econometrics 54:159-178.

Mackinnon, J.G. (1991). Critical Values for Cointegration Tests. Chapter 13 - Long-run Economic Relationships. In: Engle, R.F. and Granger, C.W.J. (Editors), Readings in Cointegration. Oxford: Oxford University Press.

Masih, R. and Masih, A.M.M. (2000). A Reassessment of Long-run Elasticities of Japanese Import Demand. Journal of Policy Modelling, 22, 5: 625-39.
Mbanga, G.N. and Sikod, F. (2001), The Impact of Debt and Debt Service Payments on Investment in Cameroon. A Report Presented at the AERC Biannual Research Workshop, Nairobi.

Mwaba, A. (2001). External Debt and Debt Reduction Measures in Uganda. Paper prepared for the WIDER Conference on Debt Relief, Helsinki. 17-18 September.

Newey, W. and West, K. (1994). Automatic Lag Selection in Covariance Matrix Estimation. Review of Economic Studies, 61: 631-53.

Osterwald-Lenum, M. (1992). A Note with Quantiles of the Asymptotic Distribution of the Maximum Likelihood Cointegration Rank Test Statistics. Oxford Bulletin of Economics and Statistics, 54: 461-471.

Phillips, P.C.B. and Perron, P. (1988). Testing for a Unit Root in Time Series Regression. Biometrika, 75: 335-346.

Sachs, J. (1989). The Debt Overhang of Developing Countries. In: Calvo, Guillermo A. et al (Editors), Debt, Stabilization and Development: Essays in memory of Carlos DiazAlejandro. Oxford: Basil Blackwell.

UNECA (1998). The Dynamic Impact of External Debt Accumulation on Private Investment and Growth in Africa. UNECA Working Paper Series.

Were, M. (2001). The Impact of External Debt on Economic Growth and Private Investment in Kenya: 1970-1996: An Assessment. UNU/ WIDER Discussion Paper, DP2001-120, Helsinki.

Zupi, M. (2003). Is Pooling Data a Reliable Method of Empirical Argumentation Relating to African Development? Paper presented at the 2nd General Conference of the European Consortium for Political Research (ECPR), Marburg, Germany, Centro Studi di Politica Internazionale (CeSPI) and Roskilde University, 18-21 September. 